\section{THE EGYPTIAN PAPYRUS, PAST AND PRESENT.} BY GUY E. MTTCHELL.

The papyrus plants of ancient Egypt are not all dead, though papyrus paper making is a long-lost art. As a beautiful ornamental plant the papyrus thrive to-day, and is perhaps destined to become a favorite along the banks of our warmer streams and rivers. In Florida or Louisiana in a noiseless electric launch th visitor may then glide up creeks and winding rivers, and drift back some thousand years into the dim and hazy days when the Pharaohs and the Ptolemies and Cleopatra ruled the land of earliest civilization

In the days of paper-making Egypt, the banks of the Nile near the sea must have been covere with great stretches of this wonderful plant. The bassreliefs on Egyptian monuments show the methods of this culture, while the great Alexandrian library with its half mil. lion long papyrus rolls, burned by the ruthless Mohammedans, gives an idea of the extent of its use. Alexandria was the center of its manufacture, and throughout the Nile delta were large plantations of this graceful and lordly plant.

As late as the eighteenth century travelers in Egyp found the fellaheen or peasants making mats of papyrus, although the art of paper making has been lon dead. To-day you may search lower Egypt in vain for a single plume of papyrus, although on the uppe reaches of the Nile you can still lose yourself in its dense forests, which everywhere line the banks of the sluggish river. The few plants now growing in the Ezlee Kieya garden in Cairo are said to have been im ported there from Hamburg.

It seems strange that a plant which ol. se played such a rôle in the world of literature an history should have become so neglected that probably not one in ten thousand of the people of the United Stat could tell what it is like or would know it if the saw it, except that they would recognize a plant sur passingly beautiful.

The papyrus of old Egypt would add an irresistible charm to our southern waterways. To enthusiasts on beautiful plant forms it were well worth a visit to Sicily just for a look at the miles of papyrus which overhang the Anapo River, as well as its source, a deep clear spring just outside the ancient city of syracuse. It is difficult to conceive a more brilliant or more fairy-like sight than the thousands of smooth, slender, leafiess stems, rising in graceful curves from the water to a height of fifteen feet and bearing at their summits feather-duster tassels of delicate green filaments. As the boat winds in and out among this multitude of smooth stems, or as you separate the tassels which nearly touch overhead, it is easy to believe yourself in a tropical forest, where all the tree trunks are brilliant green and all the leaves are threads of but a lighter vivid hue. This wealth of papyrus on the Anapo is one of the most fascinating sights in the world, and every year thousands of visitors make the excursion from Syracuse to view it.

If the experiments which are being started with the papyrus by the Office of Plant Introduction of the Department of Agriculture are as successful as Mr. Fairchild, the agricultural scientist in charge of the office, hopes, that plant may yet become a favorite ornament in Florida, where many streams like the Anapo are to be found, and where thousands of visitors repair annually to look upon and enjoy strange plants and fruits and to thaw the cold and frost from the marrow of their bones.

Recent excavations at Abusir have brought home the universal importance of papyrus in illuminating many a dark spot in ancient history and literature. In one of the graves at Abusir was discovered, on February 1, 1902, a papyrus roll containing a large portion of the poem Persai of Timotheus. The papyrus was found in a wooden coffin still containing its corpse, together with a pair of sandals, a broken leather bag, a piece of rust-eaten iron, and a fragment of burned wood. All these objects are now at the Royal

Museum of Berlin, and the papyrus has been published with a transcription, paraphrase, comments, and a facsimile reproduction in heliogravure, by Prof. Dr. Ulrich von Wilamowitz-Moellendorff. The papyrus measures 185 centimeters in height and when unrolled has a length of 1.11 meters." It is inscribed with six columns of varied width and unequal number of lines in archaic Greek characters, resembling the style of monumental inscriptions, so that in the opinion of

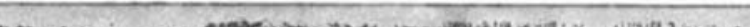

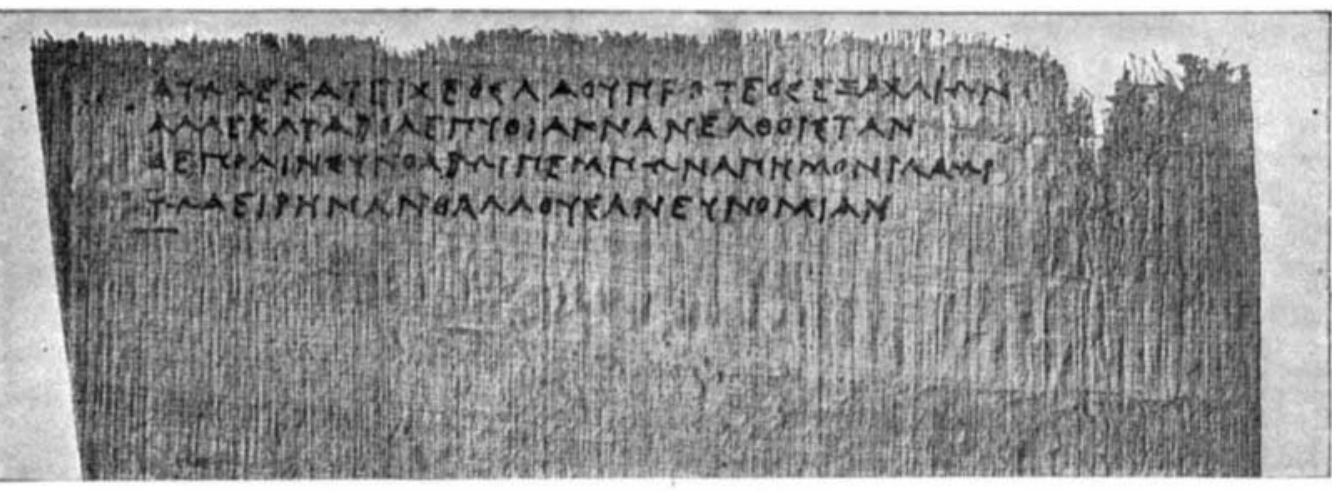
ATtixeds

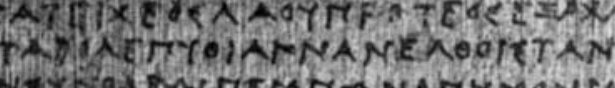

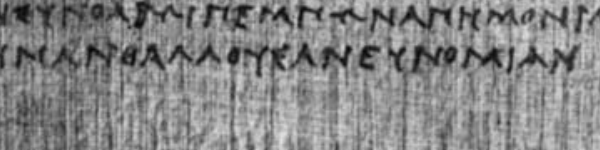

Timotheus Papyrus, Column VI.

Xerxes, the King of Persia, in 480 B. C. at Salamis, which was one of the decisive battles in the GræcoPersian wars. Timotheus was a celebrated poet and musician who was born at Miletus, Asia Minor, and died at an advanced age about 357 B C. and died at an advanced age about $35 n$ B. C. so-called "nome," an ancient song or ode in the epic style, consisting of a narrative interwoven with speeches of introduced characters, and sung to the accompaniment of the lyre by the poet himself on festival occasions in honor of some god. $\mathrm{He}$ is also recorded to have in creased the number of the strings of the lyre to eleven, by which innovation he incurred the displeasure of the Spartans, who considered it to be a corruption of music. But of the numerous compositions credited to him by later writers only a few fragments survive, and of the Persai only three verses were known. The Persai is also in the form of a nome and was first recited at the Panionion festival in honor of

Prof. Wilamowitz this papyrus represents the oldest book known, antedating the founding of the library of Alexandria and the establishing of the Alexandrian book trade. The last four columns are on the whole well preserved, while the first column, not prctected by covering, is crumbled into minute fragments and of the second column the lower half $i_{i}$ for the most part destroyed. A narrow margin on the first column, showing traces of having been cut through, proves that only part of the scroll had been deposited in the grave. We have, therefore, in this papyrus only the latier portion of the work. The fact, however, that simotheus names himself as its author and that it treats of the naval defeat of a Persian king suffices to establish its identity with the Persai of Timotheus, which celebrates the naval victory of the Greeks over

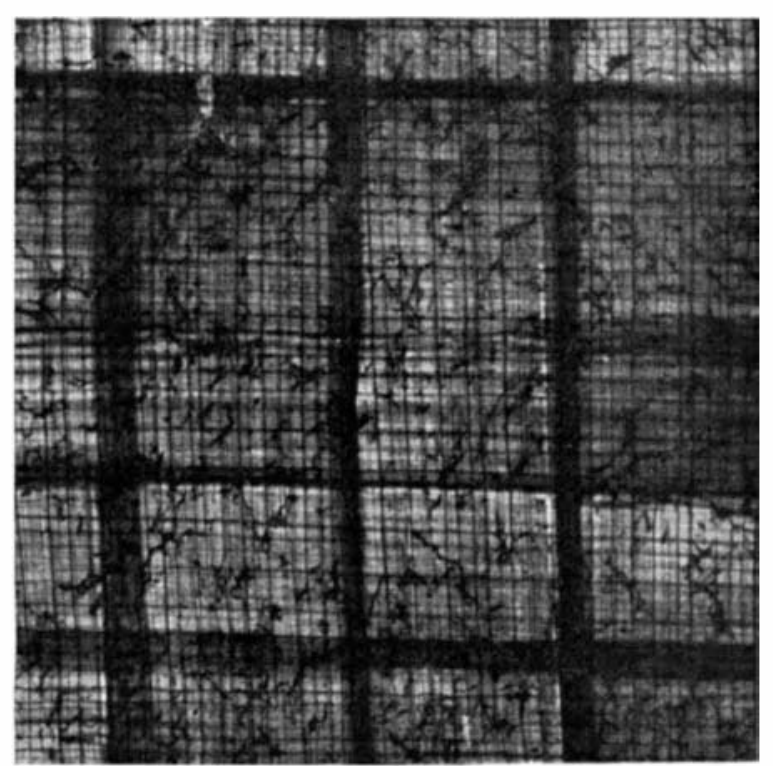

What Papyrus Looks Like when Held Up to the Light.

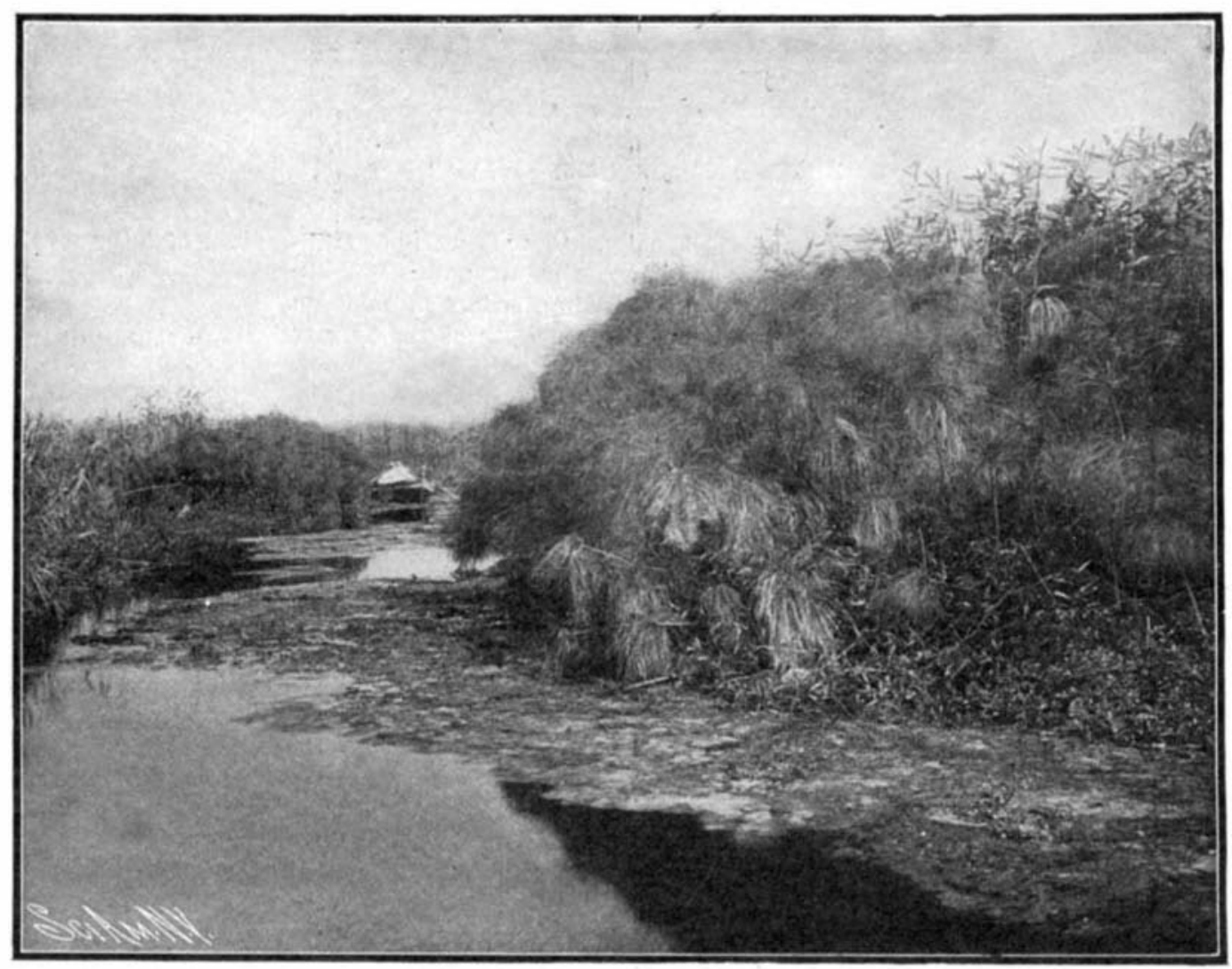

Papyrus Growing on the Banks of a River Near Syracuse.

THE EGYPTIAN PAPYROS, PAST AND PRESENT.
Poseidon, about 398 B. C. The part of the nome contained in this papyrus begins with the principal section of the poem, the omphalos, comprising the na rative. The ships are fitte out; the battle begins; the vessels dash against each other; lances fly about; firebrands whirr in the air, setting the ships afire, from the glare of which the "smaraged" sea is reddened. The Persian leet is put to flight; one rich follower of the Persian king battles with the waves, cursing the treacherous sea, and at last sinks while professin his hope tor the victory of his king. Other Asiatics cling to rocks in the sea and bewail their imminent fate of death or captivity. At last panic seizes also the royal headquarters, and the king, under lamentations, orders a general retreat of his motley army. The victorious Greeks erect a trophy to Zeus and celebrate their victory with dance and song. In the epilogue the poet refers to himself, defending his innovation in music against the reproof of the Spartans, and invokes Apollo to "give the people peace and blessing resting on the observation of the law."

The German Naval Estimates for 1905.

According to the recently published estimates for the German navy for 1905 , several important additions are contemplated. Hitherto Germany has regarded the submarine vessel as being still in an experimental stage, but owing to the progress of development of this craft by other powers, a sum of $\$ 375,000$ is to be devoted to the purposes of carrying out experiments with a view to finding the most suitable type of submarine boat for use in the German navy. Special at tention is to be devoted to artillery armaments, upon which $\$ 7,317,750$ is to be expended. This represents an increase of $\$ 1,686,250$. Owing to the employment of stronger armor plating for ships and the increased range of the guns of the navies of the other maritime nations, the power of the biggest and medium-sized weapons is to be considerably augmented. There is to be an appreciable increase in the quantity of ammunition carried by the battleships and armored cruisers. Furthermore, the lighter guns signed fundamentally for repeling torpedo-boat attacks are to be considerably increased in their power, to render them better fitted for this work. At the same time a corresponding augmentation of the armaments of the torpedo boats is to be carried out, and a new and more serviceable type of torpedo boat is to be designed for the Imperial navy.

Experiments have been car ried out by the fire brigade au thorities of Manchester, Eng. with a new type of helmet. I is especially designed to facilitate the penetration of dense masses of smoke. The helmet is equipped with incandescent electric lamps, while an air current is directed upon the eyes and nostrils to protect them from smoke. The equipment is completed with a telephone apparatus, so that the fireman when he enters a building can always maintain communication with the force outside, ind if necessary summon asisistanco. 